\title{
Reporting and Disclosure of Investments in Sustainable Development
}

\author{
Piotr Staszkiewicz *(D) and Aleksander Werner \\ SGH Warsaw School of Economics, 02-554 Warszawa, Poland; awerne@sgh.waw.pl \\ * Correspondence: pstasz@sgh.waw.pl
}

check for updates

Citation: Staszkiewicz, P.; Werner, A. Reporting and Disclosure of Investments in Sustainable Development. Sustainability 2021, 13, 908. https://doi.org/10.3390/ su13020908

Received: 11 December 2020

Accepted: 13 January 2021

Published: 18 January 2021

Publisher's Note: MDPI stays neutral with regard to jurisdictional claims in published maps and institutional affiliations.

\begin{abstract}
This paper builds upon prior research regarding the quest for a sustainable measuring method. Here, we present a method to integrate sustainability and financial accounting at the level of transaction recording and introduce the concept of environmental debit and credit entry. This concept is illustrated through investment reporting. Identification of the research gap is based on the review of the initial population of 141 research papers and is supported with the European legal framework analysis. Logistic regression on the 500 largest European-based companies justifies the environmental footprint inclusion into the integrated journal entry. This study provides robust data concerning the limitations of the current financial reporting system. Our findings support the conclusion that the currently applied hybrid sustainable disclosure with synthetic ratios, indicators and unstructured narratives failed to provide a comprehensive and auditable picture of a company's environmental.
\end{abstract}

Keywords: triple accounting; momentum accounting; Agenda 2020; CSR reporting; financial reporting; company footprint; sustainable investments; COVID; integrated reporting; auditing

\section{Introduction}

This study presents an environmental perspective in financial reporting regarding the disclosure of investments. The study fits into the broader context of the discussion on possible paths for measuring human impact on the environment. The COVID-19 stress tests accelerate the search for the potential digitalization of multi-dimensional communication [1-8] and promote a search for new paths for information digitalization and transformation.

Financial reporting is based on the model of aggregation of economic transactions in a double-entry system. It is probably the oldest arithmetic and business concept in economic practice, dating back to at least the 14th century [9]. Hence, both the mechanism and the purpose of registration were narrowly defined. At the end of the 20th century, man's economic activity upset the global balance of the ecosystem [2], the effects of which we can now see with the naked eye. However, the foundation of measurement and reporting is still unchanged. Without information about the real impact of human beings on the environment, neither management, nor owners, nor political decision-makers, can make fully informed decisions [3].

This study outlines the concept of a multi-purpose record as a mechanism for changing the financial reporting model to reflect the effects of human use of the environment. It also fills a gap in the discussion of integrated business reporting with a proposal to record environmental impacts at the level of individual transactions as opposed to the currently used synthetic indices or descriptive disclosures.

\section{Overview of the Main Reporting Trends}

Over the last thirty years, there have been eight developments in corporate financial reporting. First, the volume of financial statements is increasing. Standard compliance reporting systems (e.g., the case of Poland during the socialism period and thereafter) used a universal chart of accounts, and the aggregation of it was rigid. That is, it was 
constrained by financial regulations. Deviation from the rigid and universal concept of the chart of accounts resulted in the development of different types of accounting options within given standards. This contributed to the need to disclose accounting policies in financial reporting.

Second, the principles of financial reporting are being unified. While the United States Generally Accepted Accounting Principles (US GAAP) prevailed in the 1980s against the backdrop of dispersed national systems at the beginning of the 21st century, Europe adopted International Financial Reporting Standards (IFRS) reporting as its basis. This gives rise to two equivalent financial reporting systems and a slow reduction in the diversity of national systems and their convergence toward IFRS.

Third, to guarantee the universality of the IFRS in its design (unlike US GAAP), there is a conceptual framework: the equivalent of general principles in the legal system. The conceptual framework in IFRS is dynamic, and the standards are slowly becoming more detailed and interchanged (e.g., selective implementation by the European Commission and Council). As a result, IFRS is subject to conceptual inflation over time, and the quantity of firms converting to US GAAP [10] is growing, causing a mirage of an instructional system via a conceptual system. This has resulted in the bloating of additional information and its descriptive nature.

Fourth, the complexity of business transactions is increasing [11]. Financial instruments, the fair value concept, risk management, the prudential reporting model (now integrated into IFRS and US GAAP), and the risk concept of a set of transactions, as opposed to the risk of an individual transaction, are emerging. Moreover, financial reporting has not kept pace with changes in the global asset structure; the increasing value of entities is shaped by intangible assets (e.g., number of patents), development and research expenditure, relationship monetization, and brand and trademark value, with balance sheet aggregates of these items having low interpretative value.

Fifth, related party transactions, off-balance sheet and guarantee transactions, the arbitrariness of fair value measurements for inefficient markets, and the development of complex derivative financial instruments such as credit default swaps (CDS), contract for differences (CFDs), unit-link, and similar items are increasing in the same stream of business developments. In this context, both financial and managerial accounting failed to adhere to business reality. Haslam et al. [12] point out that there is even contradiction in understanding management accounting by different types of stakeholders. Thus, the tendency to catch up with the growing gap is addressed through risk management and risk disclosure. For example, Durst et al. [13] indicate that knowledge of risk management strengthens an entity's competitive advantage. However, effective risk management stimulates the digitalization of the data.

Sixth, financial reporting is digitized. The U.S. Securities and Exchange Commission (US SEC) first introduced an obligation for supervised entities to transmit data electronically to the supervisor. The turn of the century sees the implementation of eXtensible Business Reporting Language (XBRL) $[14,15]$ as an electronic data-reporting standard. Europe is introducing such an obligation in 2020.

Seventh, under pressure from green shareholders (who incorporate the environmental criteria into the decision process), companies have started to publish environmental impact information as part of, or in parallel with, financial reporting. For the time being, Corporate Social Responsibility (CSR) reporting is unstructured and does not necessarily meet the conditions for horizontal and vertical comparability between entities and within groups. CSR reporting is primarily a narrative complement to financial reporting, as it is currently not integrated at the level of recording individual economic events, although it is slowly being standardized [16]. The CSR is claimed to be unstable [17] and poorly integrated in financial reporting [18] and weakly understood [19].

Eighth, the combination of trends in the digitization of the general ledger, cloud transactions, and the standardization of reporting rules reduces transaction costs and 
tensions on the agent/master line. As a result, the current financial audit is moving away from records to operational consulting.

In IFRS design, unlike US GAAP, there is a conceptual framework that is the equivalent of general principles in the legal system [20]. The conceptual framework in the IFRS is dynamic, and the standards are slowly becoming more detailed and interchanged (e.g., selective implementation by the European Commission and the council). As a result, IFRS is subject to conceptual inflation over time, and the volume converting to US GAAP is growing [21]. This has resulted in the bloating of additional information and its descriptive nature, which opens space for misuse, e.g., covering up unfavorable information [22].

The related party transactions, off-balance sheet, and guarantee transactions, arbitrariness of fair value measurements for inefficient markets, and the development of complex derivative financial instruments such as CDSn, CFDs, unit-link, and the like are increasing in the same stream of business developments. Financial reporting addresses those changes mainly through narratives and has failed to account for value creation changes from tangible assets to intangible [23].

Despite the relatively intensive development of financial reporting, the foundation on which it is based, namely the accounting system, has not changed for centuries. The solution offered by practice boils down to increasing the volume of financial statements through an excessive unstructured description of test transaction characteristics. The user of financial statements receives an excessive amount of information and, combined with natural cognitive constraints, cannot rationally process, aggregate, and compare the information. This situation results in a tendency to make increasing use of machine analysis (e.g., text mining) [24] that is burdened with a large error in the analytical model itself. Despite the practical application of advanced tools for data analysis and aggregation, information about the environmental impact of business units is lost based on the system. Therefore, this study identifies a research gap consisting of the fact that the currently used double-entry system only transfers information about the transactions' economic value (the verification of the research gap presents the Appendix A). Having identified the research gap, let us review the current European legal framework for integrated reporting.

\section{European Legal Background of the Integrated Reporting Implementation}

The need to adopt certain elements of integrated reporting was recognized by the European Union. Amendment to the directive on the annual and consolidated financial statements and related reports (Directive 2013/34) introduced obligations concerning disclosing certain non-financial and diversity information (Directive 2014/95). Non-financial statements should be included in the management report or a separate report. Directive 2014/95 defines the minimum content of the non-financial statements, which includes, inter alia, environmental, social, and employee matters [25]. It is hard to make a conclusive assessment of the adopted solutions [26], particularly while taking into account a broader perspective on global development to the integrated reporting concept $[27,28]$.

On the one hand, in some Member States, there was an obligation to disclose nonfinancial reports (e.g., the UK, Sweden, Spain, Denmark, and France) and undertakings often published reports on their initiative to present their business as socially responsible [29]. The European Commission's analysis showed that the information disclosed in non-financial reports was often lacking in materiality or was not sufficiently balanced, accurate, and timely [30]. Hence, there was a need to establish a certain minimum legal requirement in the directive and make non-financial reports available to the public.

On the other hand, the EU's harmonization scope is very limited and leaves a wide margin of discretion for the Member States [31]. First, this concerns a small population of undertakings that should apply regulations (around 6000 large companies and groups across the EU [32] and in Poland approximately 300 [33]). The obligation to disclose is only applicable to certain large undertakings that are public-interest entities.

Second, Directive 2014/95 does not specify the material scope of obligations and gives companies significant flexibility to disclose relevant information (reporting on a 
"comply or explain" basis). The Commission's guidelines on the methodology for reporting non-financial information do not solve the problem because they are also at a high level of generality. Complaints concern an international (United Nations Global Compact) or national set of guidelines (based on ISO 26000 Social Responsibility).

Third, there is no legal obligation regarding auditing reports and directives limited to checking by the statutory auditor regarding whether the non-financial statements have been provided. Stakeholders should be certain that non-financial reports give an accurate and fair view of the company's financial position. This aim could be achieved only during an audit that is compliant with the auditing defined standards.

Finally, costs incurred in relation to the drafting and publication of a report and specific staff training or data collection costs may vary depending on the scope and content and a possible review. According to the European Commission's calculations, the disclosure cost was estimated to be between $€ 600$ and $€ 4300$, typically requiring about two working weekstime per year per company, thus generating a total cost between 10.5 and 75.25 million euros [30]. The commission has looked into the alternative of considering the costs of full mandatory reporting, and those costs were estimated in a range varying between $€ 33,000$ and $€ 604,000$ per year per company, depending on the company's size and complexity, including verification costs [34], p. 83. Actual costs incurred by the concerned undertakings were at the level of $€ 100,865$ per annum where the lowest cost was to apply the Organisation for Economic Co-operation and Development Guidelines for Multinational enterprises ( $€ 1096$ per annum) and the highest cost was to apply the Task Force on Climate Related Financial Disclosures (€ 493,000 per annum)[35], p. 22.

The range of integration within European Union law and implementation of the Directive 2014/95 is broad. Full integration would be too expensive for undertakings, but implemented limited integration has failed to meet the hopes placed upon it-even if, in 2019, the European Commission began to discuss the possible revision of Directive 95/2014/EU [31]. This paper offers a contrary solution, namely to integrate financial and environmental transaction recording.

\section{Model Concept}

The proposed solution is to introduce, instead of a double record of transactions (Dr.-Cr.) with one value, multiple records, where one transaction is recorded by the system as two double records with two different values. This system would contain two records, the first being the classic one known from the recording of economic events in Dr.-Cr., and the second part of the record would be the environmental impact of the transaction in the form of the SDr.-SCr. [36] record. Consequently, one transaction would be described by at least four technical records with at least two values of the first being financial, and the second environmental.

The model would inherit all the features of the existing financial model, but it would be different in size. That is, instead of indicating a single value (for business accounting purposes), it would indicate the value of the cost (or profit) of such a transaction for the human environment. By adding a second dimension, we complement the financial information with environmental impacts at each economic transaction level, allowing this system to inherit all aggregates used from accounting equipment, such as financial statements, taxes, public statistics, and particularly gross domestic product [37], national accounts, etc. This results in the transfer of aggregated information for the decision-maker at any organizational level, from the operational manager through to management, owner, state, and local government bodies to the national and international level.

\section{Illustration of the Model Using the Example of Investment Disclosures}

Within the conceptual model, environmental transactions are allowed, which transfer environmental value without affecting financial transactions. The proposed concept is difficult to verify with classic methods because there is no productive implementation. Therefore, until the concept is put into practice, it can be illustrated either by simulation or 
by an illustrative example. The simulation issue has been singled out for another study, including an illustrative example of the proposed concept.

Let us assume that (1) a system of multiple recording of financial and environmental values is used, (2) all values are aggregated according to the applied financial reporting standard, (3) all transactions are measured reliably, and (4) their financial and environmental value can be clearly shown at the transaction level. For illustrative purposes, environmental aggregated values are assumed arbitrarily, as the log and general ledger aggregation follow. With these assumptions, it is possible to illustrate what disclosure would look like, with and without environmental data. For this purpose, we will use the 2019 consolidated accounts of the Orlen Capital Group for "Investments in equity valuation" (see Table 1 bellow).

Table 1. Financial reporting-double-entry only investments accounted for using the equity method.

\begin{tabular}{ccc}
\hline & 31 December 2019 & 31 December 2018 \\
\hline Joint undertakings, including: & 672 & 644 \\
Basell ORLEN Polyolefins Sp. z o.o. & 640 & 612 \\
Associated undertakings & 6 & 6 \\
\hline
\end{tabular}

Source: Orlen Group consolidated financial statements 2019.

Existing disclosure does not allow for the determination of how the joint venture expenses affect the environment. Using multiple disclosures, a two-dimensional value space can be obtained. Table 2 shows the effect of extending the system to environmental value. Column F indicates the financial values over the period, and Column S indicates the environmental values (ecological footprint).

Table 2. Financial reporting - multiple environmental values investments accounted for using the equity method.

\begin{tabular}{ccccc}
\hline & $\begin{array}{c}\text { F } \\
\text { 31 December } \\
\mathbf{2 0 1 9}\end{array}$ & $\begin{array}{c}\text { 31 December } \\
\mathbf{2 0 1 9}\end{array}$ & $\begin{array}{c}\text { 31 December } \\
\mathbf{2 0 1 8}\end{array}$ & $\begin{array}{c}\text { 31 December } \\
\mathbf{2 0 1 8}\end{array}$ \\
\hline $\begin{array}{c}\text { Joint undertakings, } \\
\text { including: } \\
\text { Basell ORLEN }\end{array}$ & 672 & & 644 & \\
$\begin{array}{c}\text { Polyolefins Sp. } z \text { o.o. } \\
\text { Associated } \\
\text { undertakings }\end{array}$ & 640 & $(320)$ & 612 & $(311)$ \\
\hline & 6 & 1 & 16 & 1 \\
\hline
\end{tabular}

Source: The authors based on the consolidated financial statements of the Orlen Group 2019. Note: F-financial data, S-sustainability data.

Table 2 shows the aggregated environmental impact of the Basel investment and, in this case, it is negative. With this financial reporting structure, both the manager and the owner can directly assess the environmental impact of the business activity.

The illustration leads us to the more operational issue, namely, to the extent that environmental impact might enhance our understanding of corporate investments and environmental usage. To center our attention, consider the geographical and investment aspects-that is, if the investment value is equally distributed among countries and environmental footprints. Thus, the issue brings us to the following verifiable working hypotheses:

Hypothesis 1 (H1). The environmental footprint of investments follows the economic value distribution that allows for the testing of the extension of financial recording with environmental entries. 
Hypothesis 2 (H2). The environmental footprint of the investment is equally spread across European countries.

In turn, the $\mathrm{H} 2$ hypothesis allows us to verify the spatial effect of the recording extension.

\section{Simulation of the Geographic Distribution of Investments and Ecological Footprint 6.1. Scope of Verification}

The operational testing of the Hypotheses $\mathrm{H} 1$ and $\mathrm{H} 2$ utilizes a simplified simulation, as the historical data are not available. To capture the cross-country effects, this study applies a review of the major European entities. The study limits the scope to Europe to ascertain the comparability of the financial data (either IFRS or local standards, driven by the uniform standards of the EU directives framework). Similar auditing regulation is mainly based on the International Standards on Auditing. The limitation to Europe allows putting aside the cultural, climate, and other continent-specific characteristics, which cannot be plausible controlled at the level of the firms.

\subsection{Outline of the Method and Dataset}

The simulation starting point for this study is the sample of the top 500 companies across Europe. The sample of the cross-sectional data as of 2018 was taken from the Orbis database [38]. The sample data were geocoded as the original dataset lacks latitudinal and longitudinal completeness (compare Figure 1 and Table 3). The paper develops a simulation of the impact of investments based on the following general transformation model:

$$
E F=\text { eniromental footpirint }=\sum\left\{\begin{array}{c}
\text { intangible fixed assets } x=\left\{\begin{array}{c}
\text { goodwill } \beta=0 \% \\
\text { other } \beta=-3 \%
\end{array}\right. \\
\text { tangible fixed assets } x=3 \% \\
\text { long term investments } x=3 \%
\end{array}\right.
$$

Table 3. Definition of variables.

\begin{tabular}{cc}
\hline Name & Description \\
\hline EF & Ecological footprint value estimated based on (2) \\
Fixed Assets & Total fixed assets as of 2018 thousand USD-(FA) \\
Intangible Assets & Total intangible assets as of 2018 in thousand USD-(IA) \\
Total assets & Total assets as of 2018 in thousand USD-(TA) \\
CDS & 5 -year credit default swap spread \\
RoE & Return on equity \\
RoA & Return on assets \\
& Dependent variables (Y) \\
\hline West & Variable value of 1 for entities located in west European countries, else 0. \\
North & Variable value of 1 for entities located in north European countries, else 0. \\
\hline Source: The authors. &
\end{tabular}

The parameter $\beta$ represents a net environmental charge allocated to the specific class of investments disclosed in the firm's financial statement. There are no records of the extended journal system; thus, the rates have been ascertained as the compromise of different literature proposals. The baseline for the environmental footprint offers an analysis of the relation of GDP spent on conservation. McClanahan and Rankin [39] report the maximum value of such relations for New Zealand at $0.16 \%$. The macroeconomic values are diluted through non-profit and government organizations and likely represent only the direct expenses to maintain the environment; thus, the value can be significantly underestimated. On the other hand, the residual value could be estimated similar to the recultivation provision in the mining industry or land restoration costs in the range of \$2000- 
5000 [40] or recycling costs [41]. The maximum value of the costs should not reasonably exceed the residual value of assets at disposal, which is usually $5 \%$. Another approach is the estimation of the recycling costs per revenue unit. Klausner and Hendrickson [42], p. 157 find that the net take-back cost is approximately $6.2 \%$ of the unit revenue for the power tools industry. However, the available data are limited to a specific industry and country. Thus, the true value of the parameters might reasonably vary between $0.1 \%$ and $6.2 \%$. In general, this finding applies to the middle value of $3 \%$. The investment section of the companies reporting is not homogeneous, as there are subclasses of tangible and intangible assets. Within the intangible assets, goodwill can be recognized; however, it is a judgmental accounting entry, which has little to do with environmental impact. This paper eliminates goodwill from the environmental change, contrary to the rest of the intangible assets that might have an impact on the acceleration of the quality and efficiency of production and services, which are likely to safeguard the environment. As a result of this, the intangible assets, except for goodwill, enjoy a reduced rate of $3 \%$. The rest of the assets are charged, for simulation, with the standard $3 \%$ rate.

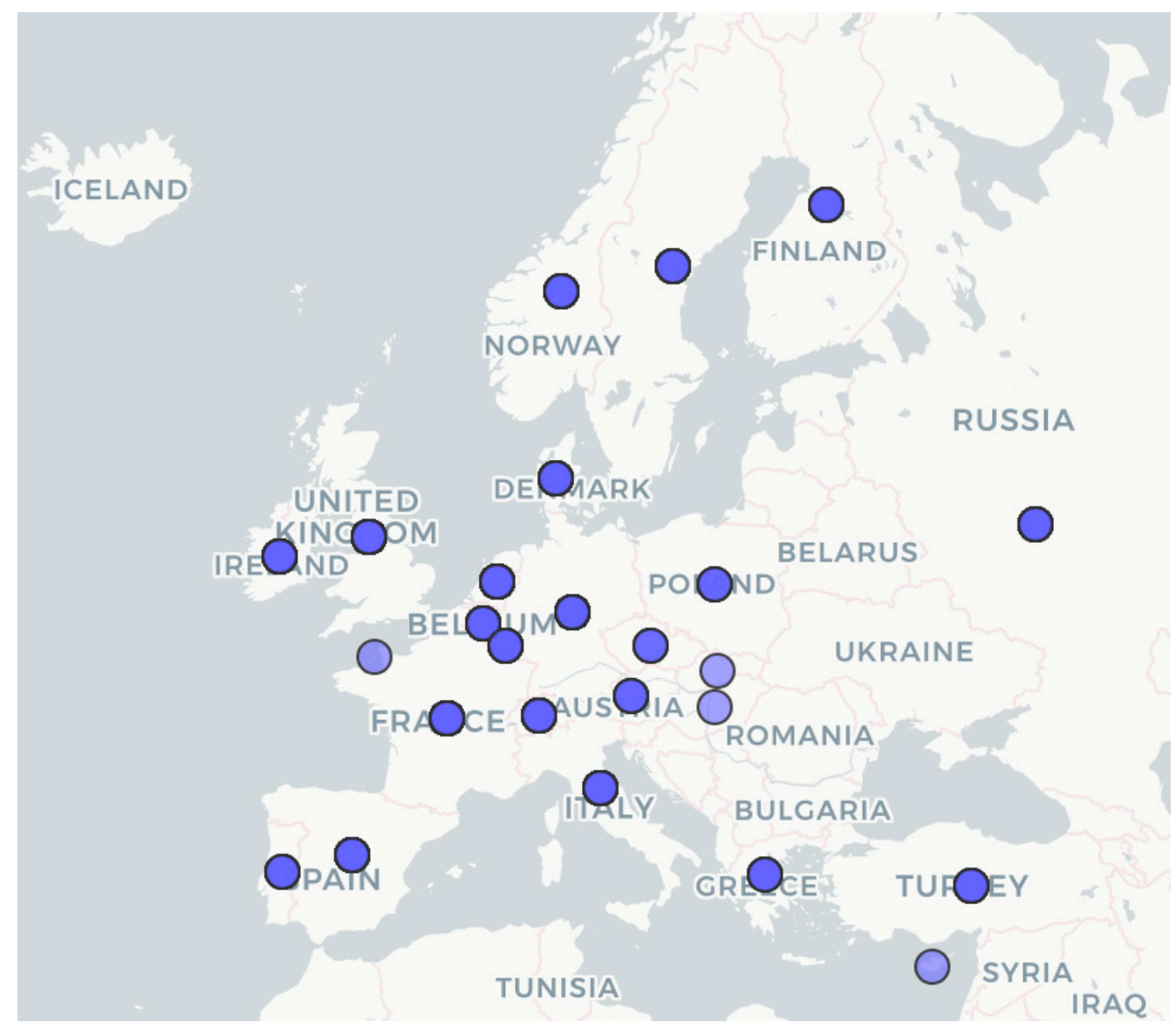

Figure 1. Sample geographical allocation by countries. Source: The authors.

To test the $\mathrm{H} 1$ hypothesis that the environmental footprint of investments follows the economic value distribution, we apply a logistic regression. The reasoning behind this test is as follows. If the ecological value of the investment follows the financial value of the investments, then the ecological value should be insignificant for the north-south and westeast investment categories (see Figure 1). In general, this paper tests the following equation:

$$
\log (Y)=\beta_{o}+\beta_{1} E F+\beta_{2} F A+\beta_{3} I A+\beta_{4} T A+\beta_{5} C D S+\beta_{6} \operatorname{Ro} A+\beta_{7} \operatorname{RoE}+\varepsilon
$$

where $\beta$ represents coefficients and $\varepsilon$ represents error. This research applies logit regression with the application of the maximum likelihood estimation, and quasi-maximum likelihood 
standard error correction was selected for the model estimation. The dependent variable $\mathrm{Y}$ is tested two-fold. First, via a binary variable representing the Western part of Europe (value 1) or other geographical areas (value 0). Second, the application of the South variable represents the South part of Europe (value 1) and the other geographical areas were coded with 0 . The independent variable of interest is the EF-environmental footprint as defined in (2). We control the performance both at the equity and asset bases representing standard controls along with default risk measured through the five-year CDS spread. Table 4 presents the variable definition uses for the research.

Table 4. Distribution of sample across the counties (panel A) and activities (panel B).

\begin{tabular}{|c|c|c|c|}
\hline \multicolumn{2}{|l|}{ Panel A } & \multicolumn{2}{|l|}{ Panel B } \\
\hline \multicolumn{2}{|c|}{ Tabulation of Countries } & \multirow{2}{*}{$\begin{array}{l}\text { Tabulation of Main Activities } \\
\text { NACE2 MAIN SECTION }\end{array}$} & \multirow[b]{2}{*}{ Freq. } \\
\hline COUNTRY & Freq. & & \\
\hline Austria & 4 & B-Mining and quarrying & 15 \\
\hline Belgium & 16 & $\mathrm{C}-$ Manufacturing & 39 \\
\hline Cyprus & 1 & D-Electricity, gas, steam, and air cond. & 9 \\
\hline Czech Republic & 3 & $\mathrm{~F}$-Construction & 3 \\
\hline Denmark & 16 & G-Wholesale and retail trade; repair o & 6 \\
\hline Finland & 7 & $\mathrm{H}$-Transportation and storage & 11 \\
\hline France & 79 & $\begin{array}{l}\text { J-Accommodation and food service } \\
\text { active. }\end{array}$ & 1 \\
\hline Germany & 56 & J-Information and communication & 10 \\
\hline Greece & 5 & K-Financial and insurance activities & 371 \\
\hline Hungary & 1 & L-Real estate activities & 2 \\
\hline Ireland & 16 & M-Professional, scientific and technic & 21 \\
\hline Italy & 32 & $\mathrm{~N}$-Administrative and support service & 8 \\
\hline Jersey (United Kingdom) & 1 & $\mathrm{P}$-Education & 1 \\
\hline Luxembourg & 11 & S-Other service activities & 3 \\
\hline Netherlands & 35 & Total & 500 \\
\hline Norway & 14 & & \\
\hline Poland & 4 & & \\
\hline Portugal & 5 & & \\
\hline Russian Federation & 16 & & \\
\hline Slovakia & 1 & & \\
\hline Spain & 19 & & \\
\hline Sweden & 12 & & \\
\hline Switzerland & 15 & & \\
\hline Turkey & 8 & & \\
\hline United Kingdom & 123 & & \\
\hline
\end{tabular}

Source: The authors. The UK comprises the majority of the companies from the top tier, as the holding companies are mainly situated close to the major financial market. Panel B supports this statement, as the majority of the activities among the sample is the K-Financial and insurance activities.

The reasoning behind the test is this: if the EF variable becomes significant, then the $\mathrm{H} 01$ and $\mathrm{H} 02$ could be jointly rejected. Thus, the enhancement of the investment reporting contributes to the discrimination power of the model and enhancement of the double entry with environmental entries would be justified (see Table 5). 
Table 5. The ecological footprint (in thousands USD).

\begin{tabular}{|c|c|c|c|c|c|c|c|c|c|c|c|}
\hline$\#$ & Country & Assets & $\begin{array}{l}\text { Tangible } \\
\text { Assets }\end{array}$ & Footprint & & $\#$ & Country & Assets & $\begin{array}{l}\text { Tangible } \\
\text { Assets }\end{array}$ & Footprint & \\
\hline & & TA & TTA & EF & EF/TA & & & TA & TTA & EF & $\mathrm{EF} / \mathrm{TA}$ \\
\hline 1 & Austria & 516,000 & 28,700 & 3.414821 & $6.62 \mathrm{E}-06$ & 14 & Luxembourg & $1,210,000$ & 322,000 & 844.37 & 0.000698 \\
\hline 3 & Cyprus & 59,500 & 0 & 0.63 & $1.06 \times 10^{-5}$ & 16 & Norway & $3,220,000$ & 0 & 3393.951 & 0.001054 \\
\hline 4 & Czech Republic & 289,000 & 69,600 & 9.28341 & $3.21 \times 10^{-5}$ & 17 & Poland & 291,000 & 0 & 28.9099 & $9.93 \times 10^{-5}$ \\
\hline 5 & Denmark & $2,420,000$ & 0 & 1599.185 & 0.000661 & 18 & Portugal & 489,000 & 561,000 & 5.124961 & $1.05 \times 10^{-5}$ \\
\hline 6 & Finland & $1,280,000$ & $8 \times 10^{5}$ & 101.6789 & $7.94 \times 10^{-5}$ & 19 & $\begin{array}{l}\text { Russian } \\
\text { Federation }\end{array}$ & $2,820,000$ & 0 & 16,700 & 0.005922 \\
\hline 7 & France & $26,100,000$ & $5 \times 10^{5}$ & 9184.062 & 0.000352 & 20 & Slovakia & 58,700 & 207,000 & 0 & 0 \\
\hline 8 & Germany & $17,700,000$ & 0 & 192.2491 & $1.09 \times 10^{-5}$ & 21 & Spain & $7,110,000$ & 11,500 & 4206.085 & 0.000592 \\
\hline 9 & Greece & 408,000 & 0 & 6.639293 & $1.63 \times 10^{-5}$ & 22 & Sweden & $1,700,000$ & 102,000 & 99.5462 & $5.86 \times 10^{-5}$ \\
\hline 10 & Hungary & 68,300 & 67,600 & 10.71782 & 0.000157 & 23 & Switzerland & $3,940,000$ & 0 & -795.027 & -0.0002 \\
\hline 11 & Ireland & $1,550,000$ & $2 \times 10^{5}$ & -3956.56 & -0.00255 & 24 & Turkey & 701,000 & 850,000 & 7.383182 & $1.05 \times 10^{-5}$ \\
\hline 12 & Italy & $7,780,000$ & 55,600 & 1209.897 & 0.000156 & 25 & UK & $40,500,000$ & 0 & 11,500 & 0.000284 \\
\hline 13 & Jersey (UK) & 124,000 & 33,600 & 1456.41 & 0.011745 & & Total & $61,004,800$ & $1,665,100$ & 5621.392 & \\
\hline
\end{tabular}




\subsection{Main Results}

Countries such as Belgium, Ireland, and Switzerland concentrate those assets with a positive impact on the environment, which suggests differences in the geographical distribution of financial and ecological investments. Table 6 presents the descriptive statistics of the model variables.

Table 6. Descriptive statistics.

\begin{tabular}{cccccc}
\hline Variable & Mean & Median & S.D. & Min & Max \\
\hline Independent & & & & & \\
West & 1 & 1 & 0 & 0 & 1 \\
North & 0 & 0 & 0 & 0 & 1 \\
\hline Dependent & & & & & \\
Fixed Assets & $25,700,000$ & 0 & $68,500,000$ & 0 & $1,090,000,000$ \\
Intangible Assets & $5,070,000$ & 0 & $16,300,000$ & 0 & $171,000,000$ \\
Total Assets & $7,680,000$ & 0 & $22,900,000$ & 0 & $248,000,000$ \\
CDS & 0.95158 & 1 & 0.76708 & 0.13063 & 10.193 \\
RoE & 12 & 9 & 17 & -13 & 169 \\
RoA & 0 & 0 & 0 & 0 & 0 \\
EF & 91,400 & 0 & 730,000 & $-4,460,000$ & $7,340,000$ \\
\hline
\end{tabular}

Source: The authors.

The average value of the EF is relatively small due to the rates conversion discussed earlier.

Table 7 presents the results of the EF discrimination, which is significant both for the West and South region determination.

Table 7. Logit estimates. Dependent variable: West or South.

\begin{tabular}{ccc}
\hline Variable & West & North \\
\hline const & $1.5^{* *}$ & $-1.7^{* *}$ \\
& -0.40 & -0.31 \\
EF & $1.1 \times 10^{-5 * *}$ & $-1.1 \times 10^{-5 * *}$ \\
& 0.00 & $-4.80 \times 10^{-6}$ \\
Fixed Assets & $1.7 \times 10^{-8 * *}$ & $-2.3 \times 10^{-8 * *}$ \\
& 0.00 & $-9.10 \times 10^{-9}$ \\
Intangible Assets & $3.2 \times 10^{-7 * *}$ & $-3.0 \times 10^{-7 * *}$ \\
Total Assets & 0.00 & $-1.50 \times 10^{-7}$ \\
& $-3.4 \times 10^{-7 * *}$ & $3.4 \times 10^{-7 * *}$ \\
CDS & 0.00 & $-1.40 \times 10^{-7}$ \\
& $-0.65^{*}$ & -0.32 \\
RoE & -0.39 & -0.27 \\
& -0.01 & -0.0032 \\
RoA & -0.01 & -0.0085 \\
& -2.30 & $8.4^{*}$ \\
$\mathrm{n}$ & -3.70 & -5 \\
$\mathrm{R}^{2}$ & 500 & 500 \\
$\ln$ & 0.07 & 0.03 \\
& -270.00 & -160 \\
\hline
\end{tabular}

Standard errors in parentheses. ${ }^{*}$ indicates significance at the $10 \%$ level, ${ }^{* *}$ indicates significance at the $5 \%$ level. For logit and probit, R2 is McFadden's pseudo-R2. Source: The authors.

\subsection{A Robustness Check}

Both models are extended with the variables regarding the quality of the data (binary variable codes 1 for modified opinion, 0 else) and the type of the reporting standard (binary variable 1 for IFRS, 0 else). The controls turned to be insignificant. 


\section{Discussion and Conclusions}

This paper proposes a change in the way business transactions are recorded. The current double-entry system is replaced with a multi-entry system. The key difference is in a mutual recording of both financial and environmental values in two charts of accounts. The multi-entry system provides assurance of linking both financial aspects and environmental values at the transaction level. It results in the possibility to produce multi-dimensional integrated reporting. As a consequence, the multi-entry system needs less descriptive and narrative notes for the reporting. Consequently, the reporting comes back to its roots and presents aggregated data in a consistent way. This attribute allows the multi-entry system to contribute to the solution of mutual reporting of corporate financial and environmental impact.

The key findings from the simulation are that the EF is a significant variable to discriminate the geographical allocation. Thus, the actual modeling of the sustainable impact of business on the transaction level leads to enhancement of the information value transferred by the business entities to the stakeholders, mainly society. The enhanced journal entry model in its simplicity is elegant and, probably, unlike the triple entry model [43-49], it can be applied in practice by simply extending the journal entry posting instructions of an accounting document (both in manual and electronic systems). In contrast to recording the costs of using the environment only as transactions with sovereignty (receivable/payable for the use of the environment by an entity), it provides stakeholders with atomized information on the entity's environmental impact. Since it inherits the structure of financial information, classical financial analysis tools can be adapted to environmental analysis (e.g., break-even point for the environment), human resources disclosure [50], insolvency prediction [51], even to such a remote area as the efficiency of the law's impact on a business (for an extended discussion of the efficiency aspects, refer to the outline offered by Kozhokar [52]). The model is probably also suitable for the supplementary disclosure of the human resource aspects, as analyzed by Bulut Sürdü et al. [50]. Further research is needed in the context of the valuation basis. On the other hand, the implementation of the model would require an incremental effort from the side of education, as Cernostana [53] already identified as one of the model's limitations.

The practical application of the proposed concept is limited by the legal system. As financial reporting rules have the characteristics of a legal standard, it is impossible to apply this concept until the law is changed. Therefore, the proposed concept may develop in the field of management accounting, because in this system, the decision to apply environmental reporting is made by the stakeholders.

The proposal assumes the reliability, coherence, and measurability of environmental transactions. These are quite strong constraints, and, therefore, an environmental and financial review mechanism should be included to avoid excessive transaction costs. Some friction might occur in terms of auditing for integrated reporting and governance structure (see Dobija [54] for an examination of the relationship between audit committees and auditor interaction). However, the potential consequences for auditing require an isolated study. The paper does not compare the triple-entry and multi-entry systems, specifically in terms of the current XBRL and blockchain developments [55]. It is probable that an extended study in this direction might enhance our knowledge.

The application of the proposed solution in practice requires detailed research. The feasibility of valuing the environmental impact at the level of an individual transaction is an open question, and the classification of transactions and the way they are valued also require separate studies.

This study presents a preliminary and rather conceptual outline of the idea, but the solutions proposed may serve social policymakers to manage environmental resources more consciously and responsibly. 
Author Contributions: A.W. Legal analysis and drafting of the section, A.W. legal references consistency, P.S. all other aspects. All authors have read and agreed to the published version of the manuscript.

Funding: This research was funded by the Warsaw School of Economics, from activities number: 2020/12214 and 2020/12213.

Institutional Review Board Statement: Not applicable.

Informed Consent Statement: Not applicable.

Data Availability Statement: 3rd Party Data Restrictions apply to the availability of these data. Data was obtained from Orbis and Web of Science and are available in Orbis and Web of Science based on the discloses search cirterias.

Acknowledgments: The project has been undertaken as a sub-task for the research coordinated by A. Fierla.

Conflicts of Interest: The author declares no conflict of interest.

\section{Appendix A. Research Gap Verification Procedure}

Appendix A.1. Scope of Verification

The model presented here was developed based on observations of changes in financial reporting trends. This does not preclude the fact that other authors could develop a similar concept at the same time. Therefore, the verification of the research gap is based on citation count regression.

\section{Appendix A.2. Outline of the Method}

According to the author's knowledge, the citation count regression has not been used to verify the research gap $[37,56]$ in previous publications. It has been used primarily to limit the population of articles to perform a descriptive review of the literature. Next, the idea of using citation count regression as a supplement to meta-analysis and literature synthesis is presented.

The citation count regression method [56,57] consists of reducing a large number of articles to a smaller sample. In this method, the selection of the sample is not random, and the selected articles should be characterized by a great diversity of content. To select a sample, the properties of linear regression, especially the regression of the number of citations, are used. Metadata such as the year of publication, authors' affiliation, number of citations, etc., are used to describe the group of articles. In the model, the time-weighted number of citations is a dependent variable. The idea of selection is to select such articles that are leveraged observations. The ordinary least squares regression is used for the identification of the leveraged observation. The model equation general can be presented as:

$$
C=\alpha+\beta C V+\varepsilon
$$

where

$C$-Citation count (weighted or not)—dependent variable,

$\beta$-Vector of parameters,

$\mathrm{CV}$-matrix of control variables, $\varepsilon$-error term.

The original set of control variables includes Publication Years-number of years since publication year (in years), BigSampl - a binary variable $=1$ for a sample larger than or equal to 1000 items; 0 for a sample smaller than 1000 items, Method - a binary variable $=1$ for regression; 0 for other methods, Anglo-Saxon-a binary variable = 1 if the market discussed was one of the following: the US, Australia, Singapore, Canada, the UK, or New Zealand; 0 for other countries and regions; US - a binary variable $=1$ for the US; 0 for other countries and regions; TimeSpan - number of years for the period of the sample drawn; Samplethe size of the sample in total units taken into consideration, BusinessSupport-a binary 
variable $=1$ for research supported by the business; 0 for the remaining [56]. However, the original set could be adjusted to respond to the specific literature characteristics.

\section{Appendix A.3. Results}

The Web of Science database was searched by the keyword "e-reporting", and 141 publications were received that were included in the Social Sciences Citation Index, populations were restricted to the research areas "MANAGEMENT", "BUSINESS FINANCE", "ECONOMICS," or "BUSINESS". The result was a population that included 10 items of the literature presented below, with four items assigned several citations, so it was not advisable to use further steps from the survey pattern. Given the above, the full population was reviewed, and no proposals were identified that were consistent with the model presented. On this basis, the validity of the identified research gap was determined. The sensitivity of the results to other keywords was not checked at further stages; this aspect was left for a separate study.

Table A1. Main population of papers.

\section{Paper} Citation Count

Anonymous. Negligence Penalty Seen as New Hazaard in Careless T-and-E Reporting. J. Tax. 1961, 14, 242.

Hiller, W.E.; Finnegan, C.T. The high-yield bond market: A banker's primer. Bank. Law J. 1998, 115, 915-929. 0

Skoufias, E.; Coday, D.P. Are the Welfare Losses from Imperfect Targeting Important? Economica 2007, 74, 756-776, doi:10.1111/j.1468-0335.2006.00567.x

Yim, C. K. (Bennett); Chan, K.W.; Hung, K. Multiple reference effects in service evaluations: Roles of alternative attractiveness and self-image congruity. J. Retail. 2007, 83, 147-157, doi:10.1016/j.jretai.2006.10.011.

Ben-Shahar, D.; Sulganik, E.; Tsang, D. Funds from Operations versus Net Income: Examining the

Dividend-Relevance of REIT Performance Measures. J. Real Estate Res. 2007, 33, 415-441.

McKenzie, M.; Satchell, S.; Wongwachara, W. Converting true returns into reported returns: A general theory of linear smoothing and anti-smoothing. J. Empir. Financ. 2014, 28, 215-229, doi:10.1016/j.jempfin.2014.07.003.

Zhao, G.; Muehling, D.D.; Kareklas, I. Remembering the Good Old Days: The Moderating Role of Consumer Affective State on the Effectiveness of Nostalgic Advertising. J. Advert. 2014, 43, 244-255, doi:10.1080/00913367.2013.853633.

Aldaz, M.; Alvarez, I.; Calvo, J.A. Non-financial reports, anti-corruption performance and corporate reputation. Rev. Bus. Manag. 2015, 1321-1340, doi:10.7819/rbgn.v17i58.2687

Breevaart, K.; Bakker, A.B.; Demerouti, E.; van den Heuvel, M. Leader-member exchange, work engagement, and job performance. J. Manag. Psychol. 2015, 30, 754-770, doi:10.1108/JMP-03-2013-0088.

Yunus, S.; Elijido-Ten, E.; Abhayawansa, S. Determinants of carbon management strategy adoption. Manag. Audit. J. 2016, 31, 156-179, doi:10.1108/MAJ-09-2014-1087.

Source: identification of the research population based on the Web of Science database.

\section{References}

1. Zhang, H.-W.; Yu, J.; Xu, H.-J.; Lei, Y.; Pu, Z.-H.; Dai, W.-C.; Lin, F.; Wang, Y.-L.; Wu, X.-L.; Liu, L.-H.; et al. Corona Virus International Public Health Emergencies: Implications for Radiology Management. Acad. Radiol. 2020, 27, 463-467. [CrossRef] [PubMed]

2. Rizun, M.; Strzelecki, A. Students' Acceptance of the COVID-19 Impact on Shifting Higher Education to Distance Learning in Poland. Int. J. Environ. Res. Public Heath 2020, 17, 6468. [CrossRef] [PubMed]

3. Obrenovic, B.; Du, J.; Godinic, D.; Tsoy, D.; Khan, M.A.S.; Jakhongirov, I. Sustaining Enterprise Operations and Productivity during the COVID-19 Pandemic: "Enterprise Effectiveness and Sustainability Model". Sustainability 2020, 12, 5981. [CrossRef]

4. Nuara, A.; Trovò, F.; Gatti, N. A privacy-preserving tests optimization algorithm for epidemics containment. arXiv 2006, arXiv:2006.15977.

5. Korycki, Ł; Krawczyk, B. Instance exploitation for learning temporary concepts from sparsely labeled drifting data streams. arXiv 2009, arXiv:2009.09382.

6. Radu, M.-C.; Schnakovszky, C.; Herghelegiu, E.; Ciubotariu, V.-A.; Cristea, I. The Impact of the COVID-19 Pandemic on the Quality of Educational Process: A Student Survey. Int. J. Environ. Res. Public Health 2020, 17, 7770. [CrossRef] [PubMed]

7. Cepel, M.; Gavurova, B.; Dvorsky, J.; Belas, J. The impact of the COVID-19 crisis on the perception of business risk in the SME segment. J. Int. Stud. 2020, 13, 248-263. [CrossRef] 
8. García-Sánchez, I.-M.; Raimo, N.; Marrone, A.; Vitolla, F. How Does Integrated Reporting Change in Light of COVID-19? A Revisiting of the Content of the Integrated Reports. Sustainability 2020, 12, 7605. [CrossRef]

9. Crivelli, P. An original translation of the treatise on double-entry book-keeping by frater Lucas Pacioli. Print. Ital. Black Lett. Publ. Venice 1924, 1494, 24.

10. Fuad, F.; Juliarto, A.; Harto, P. Does IFRS convergence really increase accounting qualities? Emerging market evidence. J. Econ. Finance Adm. Sci. 2019, 24, 205-220. [CrossRef]

11. Rusli, P.; Zhao, X.; Ziebart, D.A. Transaction Complexity and the Movement to Fair Value Accounting; Gatton College of Business and Economics: Lexington, KY, USA, 2016.

12. Łada, M.; Kozarkiewicz, A.; Haslam, J. Contending institutional logics, illegitimacy risk and management accounting. Account. Audit. Account. J. 2020, 33, 795-824. [CrossRef]

13. Durst, S.; Hinteregger, C.; Zieba, M. The linkage between knowledge risk management and organizational performance. J. Bus. Res. 2019, 105, 1-10. [CrossRef]

14. Srivastava, R.P.; Liu, Q. Special Issue of JIS on XBRL. J. Inf. Syst. 2012, 26, 97-101. [CrossRef]

15. XBRL Education Recources. What is the History of XBRL? Available online: http://www.xbrleducation.com/edu/history.htm\#: $\sim\{\}:$ text=TheshorthistoryofXBRL, andauditschedulesusingXML (accessed on 28 December 2020).

16. Sun, W.; Zhao, C.; Cho, C.H. Institutional transitions and the role of financial performance in CSR reporting. Corp. Soc. Responsib. Environ. Manag. 2018, 26, 367-376. [CrossRef]

17. Waniak-Michalak, H.; Sapkauskiene, A.; Leitoniene, S. Do companies manipulate CSR information to retain legitimacy? Eng. Econ. 2018, 29, 352-360. [CrossRef]

18. Ratajczak, P. The mediating role of natural and social resources in the corporate social responsibility-corporate financial performance relationship. Manag. Decis. Econ. 2020, 42, 100-119. [CrossRef]

19. Krasodomska, J.; Michalak, J.; Świetla, K. Directive 2014/95/EU. Meditari Account. Res. 2020, 28, 751-779. [CrossRef]

20. Barker, R. Conservatism, prudence and the IASB's conceptual framework. Account. Bus. Res. 2015, 45, 514-538. [CrossRef]

21. Lin, S.W.-J.; Riccardi, W.N.; Wang, C.; Hopkins, P.E.; Kabureck, G.; Hopkin, P.E. Relative Effects of IFRS Adoption and IFRS Convergence on Financial Statement Comparability. Contemp. Account. Res. 2019, 36, 588-628. [CrossRef]

22. De Souza, J.A.S.; Rissatti, J.; Rover, S.; Borba, J.A. The linguistic complexities of narrative accounting disclosure on financial statements: An analysis based on readability characteristics. Res. Int. Bus. Finance 2019, 48, 59-74. [CrossRef]

23. Lev, B. The deteriorating usefulness of financial report information and how to reverse it. Account. Bus. Res. 2018, 48, 465-493. [CrossRef]

24. Boskou, G.; Kirkos, E.; Spathis, C. Predicting Auditors Firm with Text Mining on Internal Audit Disclosure. J. Inf. Manag. 2018, 17,1850020 .

25. COM. Guidelines on Non-Financial Reporting: Supplement on Reporting Climate-Related Information; European Commission: Brussels, Belgium, 2019.

26. Biondi, L.; Dumay, J.; Monciardini, D. Using the International Integrated Reporting Framework to comply with EU Directive 2014/95/EU: Can we afford another reporting façade? Meditari Account. Res. 2020, 28, 889-914. [CrossRef]

27. Velte, P.; Stawinoga, M. Integrated reporting: The current state of empirical research, limitations and future research implications. J. Manag. Control. 2017, 28, 275-320. [CrossRef]

28. Vitolla, F.; Raimo, N.; Rubino, M. Appreciations, criticisms, determinants, and effects of integrated reporting: A systematic literature review. Corp. Soc. Responsib. Environ. Manag. 2019, 26, 518-528. [CrossRef]

29. Habek, P.; Wolniak, R. Assessing the quality of corporate social responsibility reports: The case of reporting practices in selected European Union member states. Qual. Quant. 2016, 50, 399-420. [CrossRef] [PubMed]

30. COM. Executive Summary of the Impact Assessment of Proposal for a Directive of the European Parliament and of the Council Amending Council Directives 78/660/EEC; European Commission: Brussels, Belgium, 2013.

31. Venturelli, A.; Pizzi, S.; Caputo, F.; Principale, S. The revision of nonfinancial reporting directive: A critical lens on the comparability principle. Bus. Strat. Environ. 2020, 3584-3597. [CrossRef]

32. European Commision. Non-Financial Reporting. Available online: https://ec.europa.eu/info/business-economy-euro/ company-reporting-and-auditing/company-reporting/non-financial-reporting_en (accessed on 17 November 2020).

33. Strzelczak, M. Analiza tematyczna. In Proceedings of the Forum Odpowiedzialnego Biznesu, Warsaw, Poland, 31 March 2017; pp. $1-2$.

34. COM. Impact Assessment Accompanying the document Proposal for a directive of the European Parliament and of the Council amending Council Directives 78/660/EEC and 83/349/EEC as Regards Disclosure of Non- Financial and Diversity Information by Certain Large; European Commission: Brussels, Belgium, 2017.

35. EC. Summary Report of the Public Consultation on the Review of the Non-Financial Reporting Directive; European Commission: Brussels, Belgium, 2020.

36. Staszkiewicz, P. Multi Entry Framework for Financial and Risk Reporting. SSRN Electron. J. 2011, 254, 298-309. [CrossRef]

37. Staszkiewicz, P. Search for Measure of the Value of Baltic Sustainability Development: A Meta-Review. Sustainability 2019, 11, 6640. [CrossRef]

38. Van Dijk, B. Orbis. 2020. Available online: https:// orbis.bvdinfo.com/ (accessed on 28 October 2020). 
39. McClanahan, T.R.; Rankin, P. Geography of conservation spending, biodiversity, and culture. Conserv. Biol. 2016, 30, 1089-1101. [CrossRef]

40. Strassburg, B.; Beyer, H.L.; Crouzeilles, R.; Iribarrem, A.; Barros, F.; De Siqueira, M.F.; Sánchez-Tapia, A.; Balmford, A.; Sansevero, J.B.B.; Brancalion, P.H.S.; et al. Strategic approaches to restoring ecosystems can triple conservation gains and halve costs. Nat. Ecol. Evol. 2019, 3, 62-70. [CrossRef] [PubMed]

41. Da Cruz, N.F.; Simões, P.; Marques, R.C. Economic cost recovery in the recycling of packaging waste: The case of Portugal. J. Clean. Prod. 2012, 37, 8-18. [CrossRef]

42. Klausner, M.; Hendrickson, C. Reverse-Logistics Strategy for Product Take-Back. Interfaces 2000, 30, 156-165. [CrossRef]

43. Ijiri, Y. Three postulates of momentum accounting. Account. Horiz. 1987, 1, 25-34.

44. Ijiri, Y. Momentum Accounting and Managerial Goals on Impulses. Manag. Sci. 1988, 34, 160-166. [CrossRef]

45. Ijiri, Y. Variance analysis and triple-entry bookkeeping. Creat. Innov. Approaches to Sci. Manag. IC2 Manag. Manag. Sci. Ser. Quor. Books Westport CT 1993, 3-25.

46. Fraser, I.A.M. Triple-entry Bookkeeping: A Critique. Account. Bus. Res. 1993, 23, 151-158. [CrossRef]

47. Ijiri, Y. Triple-Entry Bookkeeping and Income Momentum; American Accounting Association: Lakewood Ranch, FL, USA, 1982.

48. Ijiri, Y.; Noel, J. A reliability comparison of the measurement of wealth, income, and force. Account. Rev. 1984, 59, 52-63.

49. Ijiri, Y. A Framework for Triple-Entry Bookkeeping. Account. Rev. 2011, 11, 745-759. Available online: http://www.jstor.org/pss/ 247368 (accessed on 12 October 2020).

50. Sürdü, F.B.; Çalışkan, A. Özsözgün; Esen, E. Human Resource Disclosures in Corporate Annual Reports of Insurance Companies: A Case of Developing Country. Sustainability 2020, 12, 3452. [CrossRef]

51. Gregova, E.; Valaskova, K.; Adamko, P.; Tumpach, M.; Jaros, J. Predicting Financial Distress of Slovak Enterprises: Comparison of Selected Traditional and Learning Algorithms Methods. Sustainability 2020, 12, 3954. [CrossRef]

52. Kozhokar, I.P. Russian Academy of Sciences Efficiency of law in the terminological apparatus of the theory of law. ВестникПермского Университета. Юридические Науки 2020, 196-225. [CrossRef]

53. Cernostana, Z. Measuring financial sustainability of private higher education institutions. 17th Int. Sci. Conf. Eng. Rural Dev. 2018, 17, 1173-1178. [CrossRef]

54. Dobija, D. Institutionalizing Corporate Governance Reforms in Poland: External Auditors' Perspective. Central Eur. Manag. J. 2019, 27, 28-54. [CrossRef]

55. Faccia, A.; Mosteanu, N.R. Accounting and blockchain technology: From double-entry to triple-entry. Bus. Manag. Rev. 2019, 10, 108-116.

56. Staszkiewicz, P. The application of citation count regression to identify important papers in the literature on non-audit fees. Manag. Audit. J. 2019, 34, 96-115. [CrossRef]

57. Tomczak, S.K.; Staszkiewicz, P. Cross-Country Application of Manufacturing Failure Models. J. Risk Financial Manag. 2020, 13, 34. [CrossRef] 